\title{
Analysis of the Public's Mental Health and the Countermeasures of Mental Health Education During the COVID-19 Epidemic
}

\section{-----An Interview Study Based on Different Age Groups of Citizens in Baise City}

\begin{abstract}
Bei Song*
Baise University, Baise City, Guangxi, China 533000

*Corresponding author.Email: 313222527@qq.com

ABSTRACT

Strengthening social and psychological counseling and humane care during the epidemic is the key to winning the epidemic prevention and control, and is an important part of social and psychological reconstruction. This research adopts qualitative research methods, through the interview different age groups of citizens of the Baise, explore the psychological change rule during the epidemic prevention and control, The research results showed that people's cognition, behavior and emotion showed orderly regularity during the epidemic., five public mental health education are put forward based on the results of the study countermeasures, in order to provide reference for epidemic prevention and control of the public mental health education.
\end{abstract}

Keywords: The COVID-19 Epidemic, Public mental health status, Mental health education, Interview research.

\section{INTRODUCTION}

Good social psychology and social mentality are not only the regulators to win the battle of prevention and control of epidemic situation, but also the thrusters of respecting doctors and protecting social atmosphere in the new era. Building a good social mentality of epidemic prevention and control can enhance the psychological immunity of the public, including doctors, and enhance the confidence of the public to deal with the epidemic. At the same time, the cultivation of this good social mentality can reduce the social contradictions during the epidemic situation and create a good environment for the fight against the epidemic situation. Pay attention to cultivate rational and peaceful social mentality, timely calm the bad mood, build the social psychological defense line of epidemic prevention and control. How to relieve bad emotions in time is an important problem to be solved in front of us, and it is also a big test to test and display the social psychological service system.

\section{ANALYSIS OF THE TREND OF SOCIAL AND PSYCHOLOGICAL CHANGES DURING THE EPIDEMIC}

This study randomly selected people aged between 7 and 70, divided into juvenile groups (7-18 years old), Young adults (19-45 years old), Elderly group (50-70), Interviews, According to the development of epidemic situation in China, The development of the new coronavirus is divided into, Pre-epidemic (December 2019-January 2020), mid-epidemic (February-March 2020), post-epidemic (April 2020-present), Through the practice sequence change detailed understanding the epidemic situation prevention and control period Baise city people's psychology change, In this study, we studied the cognitive changes, emotional changes, And behavioral changes, They are as follows: 


\subsection{Emotional and Emotional Changes}

Emotional change is a barometer of personal mental health. As a social group animal, human beings not only have individual emotional experience, but also produce group emotion. The intergroup emotion theory (Intergroup Emotion Theory) proposed by Smith et al. holds that when individuals identify with their own social group identity, they will explain and evaluate the events related to the group from the perspective of the members of the inner group, and on this basis produce group emotions (group-basedemotions). Group emotions are easy to infect and magnify, which will have a great impact on society. With the expansion of new coronavirus and the rapid transmission of Internet information, individuals are filled with negative information. When looking at negative information, it often has a negative impact on individuals and society.

\subsubsection{People's Emotional Feelings in the Early Stage of the Epidemic are Mostly Indifferent}

At the beginning of the epidemic, most individuals were indifferent to emotion. Most people were far from their own physical and psychological distance. In the interview, a large number of interviewees said that the new coronavirus was a virus living in the news. At this time, the new crown virus to everyone is just after a meal talk, is the excuse to refuse to communicate, their mood changes little, emotional show indifference, doubt, neglect and so on in the state of emotional indifference.

Table 1. Summary of Social Individual Emotional Changes during the Baise Epidemic

\begin{tabular}{l|l|l}
\hline $\begin{array}{l}\text { Emotional ch } \\
\text { anges in the } \\
\text { Pre-epidemi } \\
\text { c }\end{array}$ & $\begin{array}{l}\text { Emotional cha } \\
\text { nges in the Mi } \\
\text { d-epidemic }\end{array}$ & $\begin{array}{l}\text { Emotional ch } \\
\text { anges in the } \\
\text { Post-epidem } \\
\text { ic }\end{array}$ \\
\hline $\begin{array}{l}\text { It doesn't mat } \\
\text { ter, doubt, ig } \\
\text { nore, gloat, e } \\
\text { motional chan } \\
\text { ge }\end{array}$ & $\begin{array}{l}\text { Nervous, terribl } \\
\text { htened, desperat } \\
\text { e, anxious, afra } \\
\text { id, disappointed } \\
\text {, angry, insecur }\end{array}$ & $\begin{array}{l}\text { Relax, be hap } \\
\text { py, be gratef } \\
\text { trust, be hap } \\
\text { py, be excite } \\
\text { d, be lucky, }\end{array}$ \\
\hline
\end{tabular}

Source: Based on the results of interviews

\subsubsection{Epidemic Period, People's Emotional State was Negative}

With the outbreak of Xinguang virus in the whole country, after the first case in Baise City, the mood changed from passive to active negative. In the interview, most of the interviewees said that when they learned that Wuhan had fallen and Baise had a case, they suddenly woke up.

\subsubsection{The Emotional State of the People in the Post-epidemic Period is Positive}

At this time, national prevention and control has made periodic achievements, Baise has also resumed labor, the city has no new cases, no cases of infection. In the interview, most citizens said they were very happy, looking forward to early work, very grateful that they had not been infected, and deeply impressed by China's hard core in the prevention and control of the epidemic, and very proud to live in Baise. I am very proud to be a Chinese. Positive emotions are conducive to effective coping with severe stress / adversity, and also help individuals recover from negative emotions. It can be seen that at this time, the people and emotions are gradually replaced by positive, and produce high patriotic feelings, aesthetic feelings, reflect the feeling of self-realization.

\subsection{Behavior Changes}

Table 2. Summary of Social Individual Emotional Changes during the Baise Epidemic

\begin{tabular}{|c|c|c|}
\hline $\begin{array}{l}\text { Pre-epidemic } \\
\text { behavior }\end{array}$ & $\begin{array}{l}\text { Mid-epidemic } \\
\text { behavior }\end{array}$ & $\begin{array}{l}\text { Post-epidemic } \\
\text { behavior }\end{array}$ \\
\hline $\begin{array}{l}\text { Do not wear } \\
\text { masks, normal } \\
\text { social, ridicule } \\
\text { the epidemic, } \\
\text { do not pay } \\
\text { attention to the } \\
\text { epidemic, go } \\
\text { out more, } \\
\text { party, do not } \\
\text { cooperate with } \\
\text { more behavior. }\end{array}$ & $\begin{array}{l}\text { Wear masks, d } \\
\text { o not go out, } \\
\text { pay attention t } \\
\text { o changes in t } \\
\text { he epidemic, } \\
\text { wash hands fr } \\
\text { equently, steril } \\
\text { ize, pay attenti } \\
\text { on to hygiene, } \\
\text { do not party. } \\
\text { There is muc } \\
\text { h cooperation. }\end{array}$ & $\begin{array}{l}\text { Wear masks, } \\
\text { wash hands fre } \\
\text { quently, steriliz } \\
\text { e, pay attentio } \\
\text { n to hygiene, } \\
\text { pay less attenti } \\
\text { on to changes } \\
\text { in the epidemi } \\
\text { c, go out less, } \\
\text { and get toget } \\
\text { her less. There } \\
\text { is much coop } \\
\text { eration. }\end{array}$ \\
\hline
\end{tabular}

Source: Based on the results of interviews

\subsubsection{People's Behavior in the Early Stage of Epidemic Situation is Passive Exclusion}

People's behavior is a habitual pattern, stable and not easy to change. When a new situation occurs, people have to change their existing behavior habits, which can cause personal discomfort and therefore often lead to exclusion. Most people at this stage also neglect to manage their own behavior, mostly psychological knowledge, but behavior unwilling to cooperate. As shown in Table 2, Baise people in the initial outbreak of passive exclusion. For example, rejection of masks, rejection of home isolation, most people say they will 
still party, will visit relatives and friends, for the campus because of isolation and have to go far away.

\subsubsection{Active Implementation of the Rules in the Middle of the Epidemic}

The progress of the epidemic at this stage has created a substantial threat to life, and people have to regulate their behavior in order to protect themselves to adapt to new changes and social rules. In interviews, most people have followed the rules to isolate their homes, wear masks, wash their hands, sterilize, no longer meet, and are no longer forced to enforce the rules.

\subsubsection{People's Behavior is Stable and Habitual in the Later Stage of Epidemic Situation}

At this stage, the epidemic rules became customary because of a long period of closure. In interviews, most people said they had developed the habit of washing their hands and wearing masks every time they went home, saying they didn't want to party much. Hope to stay at home more time with relatives.

\subsection{Cognitive Changes}

Cognition refers to the process of obtaining information and the most basic psychological process. The human brain receives the information input from the outside world, processes it through the mind, transforms it into the inner psychological activity, and then dominates the human behavior. This process is the process of information processing, that is, the cognitive process, with the development of the epidemic situation.

Table 3. Summary of changes in public perception during the Baise epidemic

\begin{tabular}{|c|c|c|}
\hline $\begin{array}{l}\text { Cognitive char } \\
\text { acteristics in } t \\
\text { he Pre-epidemi } \\
\text { c }\end{array}$ & $\begin{array}{l}\text { Cognitive } \\
\text { characteris } \\
\text { tics in the } \\
\text { Mid-epide } \\
\text { mic }\end{array}$ & $\begin{array}{l}\text { Cognitive char } \\
\text { acteristics in t } \\
\text { he Post-epidem } \\
\text { ic }\end{array}$ \\
\hline $\begin{array}{l}\text { Sense-oriented } \\
\text { cognition: listen } \\
\text { and look to u } \\
\text { nderstand the e } \\
\text { pidemic virus. }\end{array}$ & $\begin{array}{l}\text { Cognitively } \\
\text { oriented, } \\
\text { Grasp the } \\
\text { progress of } \\
\text { the epide } \\
\text { mic as a } \\
\text { whole. }\end{array}$ & $\begin{array}{l}\text { Rational thinkin } \\
\mathrm{g} \text { cognition: } \mathrm{Sc} \\
\text { ientific and rati } \\
\text { onal understand } \\
\text { ing of the epid } \\
\text { emic situation. }\end{array}$ \\
\hline
\end{tabular}

Source: Based on the results of interviews

\subsubsection{People's Cognition in the Early Stage of the Epidemic Presents the Independence of the Field Based on Feeling}

At the beginning of the epidemic situation, people know less about the new crown virus, do not know much about the epidemic situation, generally in the way of personal feelings and experience, asked how did you first understand the new crown virus? Most people mainly listen to other people say, read news reports, at this time the cognition is mainly to the new crown virus individual attribute cognition, different individuals have different understanding, the people generally take the independent self-thought as the main, less affected by the society, also appears the false cognition that the new crown virus is far from oneself, has nothing to do with oneself.

\subsubsection{In The Middle of the Epidemic, People's Cognition is Mainly Sensory Field Dependence}

With the expansion of the epidemic situation and the importance attached to the epidemic situation, the research progress of the new crown virus, the people gradually pay more attention to the cause, characteristics and social progress of the new crown virus.

In the later period of epidemic situation, people's cognition is mainly rational thinking

At this stage, the threat of the epidemic has been basically lifted, and the people have begun to calm down and think about the impact of the epidemic on themselves. At this time, more rational thinking is used, most people can recall their behavior in interviews. It is not difficult to find that in the process of epidemic prevention and control, people generally have cognitive bias, cognitive error management problems, need to be guided.

\section{ANALYSIS OF OUTSTANDING SOCIAL AND MENTAL HEALTH PROBLEMS IN BAISE CITY DURING THE EPIDEMIC}

\subsection{The Relative Fear of the Elderly and Young Children and the Relative Anxiety of the Young and Middle-aged}

Maslow's hierarchy of needs theory divides human needs into five levels, from low to high: physiological needs, security needs, love needs, respect needs and self-actualization needs. The lower the level, the greater the energy, in which physiological needs and safety needs belong to the missing type, and the influence energy on individuals is the greatest. In the interview investigation, it was found that the elderly group generally had a terrible negative emotion. On the one hand, they felt the decline of their own physiological function, on the other hand, they were induced by public opinion that the epidemic situation was unfavorable to the elderly, and generally feared, and some of the elderly had insomnia. Neurasthenia. On the one hand, children lack the necessary social experience and 
knowledge of the virus, on the other hand, they are affected by anxiety behavior from adults to treat the epidemic situation, and they are generally afraid. The negative emotions of the elderly and young children mainly come from the lack of physiological and safety needs, so the influence is more profound and the harm is great. Young adults, because of their good physical condition, more objective cognition, and not affected by the lack of needs ,78\% of young adults said they were only worried about wages, wages and other issues.

\subsection{There is a Crisis in the Isolation of Intimate Relationships at Home}

Parent-child relationship, husband and wife relationship, mother-in-law relationship and other close family relations have crisis. The interview results show that $98 \%$ of husband and wife often quarrel $97.3 \%$ of parent-child relationship is not coordinated and $87 \%$ of mother-in-law relationship is tense.

\subsection{Outstanding Problems in Family Education}

Because the school does not open, many parents say they don't know how to get along with their children. $95 \%$ of parents want their children to start school as soon as possible. Some parents say they see their children decadent at home playing games. It can only be solved by compulsion or quarrel.

\subsection{Life is Irregular and the Phenomenon of Network Dependence is Obvious}

People living in isolation mostly use online communication. In the survey, $95 \%$ of young adults were found to be online for an average of 10.5 hours a day. Most interviewees said that their isolated lives at home were completely irregular, rested at two or three o'clock in the morning, and got up at noon the next day. Three meals a day are extremely irregular. Asked about the interviewer's day schedule, 85 percent said they had no plans, played games most of the time, 78 percent said they were watching TV all day, and 82.5 percent said they expected to be arranged.

\section{SUGGESTIONS AND COUNTERMEASURES OF PSYCHOSOCIAL ASSISTANCE DURING EPIDEMIC SITUATION}

\author{
4.1. To Establish Psychological Assistance \\ Emergency Service Team, to Carry out Social \\ Psychological Assistance and Provide \\ Psychological Crisis Intervention Service in \\ Accordance with the Change of Epidemic \\ Situation in Stages
}

To set up a high-level expert group on epidemic prevention and control led by Baise College to provide psychological support and crisis intervention for epidemic prevention and control. According to the change of epidemic situation, the corresponding supportive strategies should be formulated from the perspective of social group psychology, individual psychological behavior and emergency management.

\subsection{Speed up the Construction of the Community Mental Health Service System and Develop Psychological Assistance to Adapt to Individual Emotional, Behavioral and Cognitive Changes}

Under the requirement of epidemic prevention and control, community mental health service system is particularly important. On the one hand, the psychological stress of the epidemic situation can be alleviated, negative emotions can be released, and physical and mental state can be adjusted. On the other hand, community residents can understand their mental health through counseling services, and effectively prevent and intervene the occurrence of psychological problems.

\subsection{Strengthen Guidance on Mental Health of Adolescents and Young Children, and Pay Attention to Mental Health of Elderly and Young Children}

To carry out research and analysis on cognition, emotion and coping styles of adolescents affected by the epidemic situation, especially for college students, to formulate targeted online and offline classification guidance programs, such as psychological service assistance hotline, one-to-one psychological care and crisis intervention, to guide them to look at the epidemic situation rationally and correctly express their emotions, to guide them to use constructive coping styles and behaviors, and to construct positive and effective psychological construction social network and social support system for adolescents. Popularize mental health knowledge through popular science lectures, teachers' psychological basic training and counseling hotline. At the same time, we should pay attention to the psychological changes of the elderly and the psychological trends of young children.

\subsection{Establishing a Mechanism for the Transformation of Psychological Services to Guide the Transformation of Negative Psychology into Positive Psychology}

During the epidemic period, many people show negative emotions with certain inevitability, and the people's emotions fluctuate with the development of the 
epidemic situation, so it is necessary to dialectically understand negative emotions. Long negative emotions have a negative impact on physical and mental health and career development, but short-term frustration can promote people to reflect and calm, become deep and stable. It is suggested that the purpose of social psychological service construction should be to help people overcome negative emotions through online and offline psychological professional training for teachers, cadres, community personnel and enterprise workers. Create conditions for negative emotional transformation to help people understand the truth of negative emotions.

\subsection{With the Aim of Cultivating Socialist Core Values, We Should Carry Forward Chinese Excellent Traditional Culture, Strengthen Education in Patriotism, and Enhance the Sense of Community of Human Destiny}

This epidemic situation has a great impact on people's ideological understanding. In addition to realizing the shortcomings of China's medical system and public health management system, it has aroused the consciousness of human destiny community. It is suggested that we should further guide rational patriotic education, cultivate a broad sense of health, combine individual and other people's health with national health, carry forward the virtues of family and country integration, love oneself and others in traditional culture, and add socialist core values to mental health education.

\subsection{To Build the Basic Projects of Social and Psychological Services and Appropriately Create an Atmosphere of Public Opinion for Resuming Work}

We will step up the construction and publicity of official information distribution platforms in the city, strengthen the timeliness, openness and transparency of public opinion information dissemination, and enable the general public to obtain timely information on the development of epidemic cases, treatment and discharge, the trajectory of confirmed cases, scientific and effective preventive measures, transportation and people's livelihood, etc., and build a provincial authoritative official information publishing platform to actively enhance the credibility of the government.

\subsection{Family Intimacy Assistance Programmes}

During the period of epidemic isolation, most of the family intimate relationship crisis, should provide the family with parent-child relationship, husband and wife relationship, marriage relationship, mother-in-law and daughter-in-law relationship and other intimate relationship targeted psychological assistance plan, through the platform to transfer relevant psychological knowledge, Increase social media close and harmonious relationship publicity, play praise virtue of family harmony excellent TV series.

\section{CONCLUSION}

The rapid spread of the new coronavirus and the wide range of infection are a public health emergency that is difficult to prevent and control.

This study uses qualitative research methods, through interviews with different age groups of Baise citizens, to explore the changes of people's cognition, emotion and behavior during the period of epidemic prevention and control. It is found that with the duration of the new coronavirus, people's emotion tends to be stable, their behavior tends to be rational and calm, and their cognition tends to be rational and objective. In the process of COVID-19, the elderly and children groups are more prone to fear and the relative anxiety of young and middle-aged people. There are obvious problems such as intimacy crisis, family education problems, irregular life, and Internet Dependence phenomenon. Therefore, we should set the strategy according to the epidemic process and win the decisive victory of the epidemic.

\section{REFERENCES}

[1] CAI Yanyan, Zhou Wei.Mental health education for adolescents during COVID-19 [J]. Chinese school doctor,2020,34(11):878-880.

[2] Peng Zhang, Wan Xu, Caiyi Zhang, Deloitte Geng.Investigation and analysis of public mental health status during COVID-19 epidemic [J]. Chinese school hospitals,2020,34(10):770-773.

[3] Xu Fei, Chen Yongliang, He Xiaolin.An analysis of the mental health status of college students during the COVID-19 epidemic [J]. Journal of taishan university,2020,42(05):129-136.

[5] Cui Qinghua. Survey on workers' Mental Health during COVID-19 [J]. Trade Union Information,2020(15):40-41.

[7] Zhao Fengyu Tong.The importance of psychological intervention in community stability during the epidemic [J]. Economics,2020(Z1):40-42.

[8] Ge Chuanhui, Zhao Tingting, MA Mengdi, Wu Wei, Hu Linyun, Wang Lixin, ZHANG Liangying, Song Hongmei, Zhai Changping.Investigation on public mental health status during COVID-19 epidemic $[\mathrm{J}]$. Journal of bengbu medical college,2020,45(02):159-162. 